\title{
New species of Calonectria and Cylindrocladium isolated from soil in the tropics
}

\author{
Pedro W. Crous ${ }^{1}$ \\ Godwin R.A. Mchau \\ Department of Plant Pathology, University of \\ Stellenbosch, P. Bag X1, Matieland 7602, South \\ Africa \\ Willem H. Van Zyl \\ Department of Microbiology, University of Stellenbosch, \\ P. Bag X1, Matieland 7602, South Africa \\ Michael J. Wingfield \\ Department of Microbiology and Biochemistry, \\ University of the Orange Free State, Bloemfontein \\ 9300, South Africa
}

\begin{abstract}
Several Calonectria (Ca.) and Cylindrocladium ( $C y$.) species were recovered from alfalfa-baited soil samples gathered in Colombia and Venezuela. Perithecia of Calonectria naviculata sp. nov. formed in culture when Venezuelan strains of Cy. naviculatum were crossed with ex-type Brazilian strains. $\mathrm{Ca}$ lonectria gracilipes sp. nov. (anam. Cy. gracilioideum sp. nov.), a homothallic species, was isolated from Colombian soils. Cylindrocladium graciloideum, Cy. gracile, Cy. pteridis and Cy. pseudogracile form a complex of morphologically similar species characterized by clavate vesicles and primarily 1-septate conidia. Each species could, however, be distinguished using RFLP banding patterns. A key to Calonectria spp. having Cylindrocladium anamorphs with 1-septate conidia is also presented.
\end{abstract}

Key Words: Hypocreales, mating studies, soil, systematics

\section{INTRODUCTION}

The hyphomycete genus Cylindrocladium Morgan represents species with hyaline, smooth, cylindrical conidia, and penicillate conidiophores with septate stipe extensions terminating in vesicles of characteristic shape. Where known, teleomorphs of Cylindrocladium spp. (Cy.) are best accommodated in Calonectria De Not. ( $C a$.).

More than 20 species of Cylindrocladium are recognized (Crous and Wingfield, 1994; Crous et al.,

Accepted for publication March 3, 1997.

${ }^{1}$ Corresponding author, email: pwc@maties.sun.ac.za
1995, 1997; Victor et al., 1997). Of these, Cy. gracile (Bugnic.) Boesew. (= Cy. clavatum Hodges \& May; Crous et al., 1995) has been described under various epithets, and has also been incorrectly linked to different Calonectria teleomorphs. In contrast to this species, Cy. naviculatum Crous \& M.J. Wingf. is presently known only from its type collection, isolated from soil in the Amazonas Province, Brazil (Crous et al., 1994). In the present study, several soil samples were collected from Eucalyptus plantations in South America (Colombia and Venezuela). Some of the samples rendered isolates of Cylindrocladium spp., including Cy. naviculatum and a species morphologically similar to Cy. gracile. When cultured, two previously undescribed Calonectria states were induced for these species. This report describes the hitherto unknown teleomorph of Cy. naviculatum, and characterizes the Calonectria species isolated from Colombian soil.

\section{MATERIALS AND METHODS}

Isolation and identification.-Fifteen soil samples were randomly collected from different eucalypt plantations in Colombia and Venezuela. Each sample consisted of two petri dishes filled with moist soil collected in the upper $15 \mathrm{~cm}$ soil layer in a $1 \mathrm{~m}$ radius. Dished were sealed, and transported to the laboratory, where soil samples were moistened, after which surface-disinfested ( $1 \mathrm{~min}$ in $1 \% \mathrm{NaOCl}$ ) alfalfa seeds were scattered onto the soil surface in each dish. After $14 \mathrm{~d}$, the germinating seedlings were removed from the dishes, submerged in $1 \% \mathrm{NaOCl}$ for $30 \mathrm{~s}$, rinsed in sterile $\mathrm{H}_{2} \mathrm{O}$, and plated onto $2 \%$ malt extract agar (Biolab), amended with streptomycin sulphate $(0.05 \mathrm{~g} / \mathrm{L})$ (MEA). Petri dishes were incubated for $7 \mathrm{~d}$ at $25 \mathrm{C}$ under continuous near-ultraviolet light, after which single conidia from sporulating $C y$ lindrocladium isolates were plated onto carnation leaf agar (CLA) (Crous et al., 1992). Cardinal temperature requirements for growth and cultural characteristics were determined after $6 \mathrm{~d}$ on MEA using the procedures of Crous et al. (1994). Cultures of Cylindrocladium were identified using the keys of Crous and Wingfield (1994). Wherever possible, 30 measurements were made of structures mounted in lactophenol, and extremes given in parentheses. Type 
specimens were lodged at the National Collection of Fungi in Pretoria (PREM), and ex-type cultures maintained in the culture collection of the Department of Plant Pathology at the University of Stellenbosch, South Africa (STE-U).

Sexual compatibility.-Isolates of Cy. naviculatum collected and identified in this study were mated on CLA with their ex-type strains (STE-U 627-629) in all possible combinations using the technique previously described by Crous et al. (1993a). Petri dishes were inspected weekly for perithecial development. Single conidial isolates of the Colombian species (STE-U 1153,1213 ) readily formed perithecia in culture, and were, therefore, accepted as being homothallic.

Molecular comparisons.-Morphologically the Cylindrocladium sp. isolated from Colombian soil is characterized by having 1-septate conidia and clavate vesicles. Based on these observations, it was further compared with Cylindrocladium spp. known to have clavate vesicles, and primarily 1 -septate conidia. The nuclear ribosomal DNA (nrDNA) of the Colombian Cylindrocladium sp. (STE-U 1153) was compared with ex-type strains of Cy. gracile $(\mathrm{PC} 551197,=C y$. clavatum, ATCC 22833), Ca. pteridis Crous et al. (anam. Cy. pteridis Wolf, PPRI 4157) and Ca. gracilis Crous et al. (anam. Cy. pseudogracile Crous, PPRI 4176). The nrDNA of these isolates was digested with the restriction enzymes EcoRI, HindIII and XhoI, and a Southern blot analysis was performed using the 6.3-kb ribosomal DNA repeat unit of Neurospora cras$s a$ as probe (Crous et al., 1995).

\section{TAXONOMY}

Calonectria gracilipes Crous et G.R.A. Mchau, sp. nov.

FIGS. 1-4, 9-11

Anamorph. Cylindrocladium graciloideum Crous et G.R.A. Mchau, sp. nov.

Perithecia globosa ad ovoidea, 350-400 $\mu \mathrm{m}$ alta, 300-380 $\mu \mathrm{m}$ lata, crocea ad rubra, pariete exteriore verrucosa, ostiolo papillato. Asci clavati, in stipitem longum tenuem gradatim angustatae, $80-120 \times 12-18 \mu \mathrm{m}, 8$-spori. Ascosporae hyalinae, fusiformes, 1-septatae, ad septum constrictae, (28-)33-40(-45) $\times(5-) 6-7(-7.5) \mu \mathrm{m}$. Filum septatum, hyalinum (150-)200(-260) $\mu \mathrm{m}$, in vesiculam clavatam 3(4) $\mu \mathrm{m}$ diam terminans. Rami primarii non septati vel raro 1-septati, $15-25 \times 4-5 \mu \mathrm{m}$; rami secundarii non septati, 10$15 \times 4-6 \mu \mathrm{m}$. Phialides doliiformes ad reniformes, hyali- nae, non septatae, $10-15 \times 2.5-4 \mu \mathrm{m}$. Conidia cylindrica, hyalina, 1-septata, apicibus obtusis, (35-)40-48(-60) $\times 4$ $5(-6) \mu \mathrm{m}$. Microconidiophora ignota.

HOLOTYPE. COLOMBIA. La Selva, soil, Jun. 1995, M.J. Wingfield (PREM 54417 teleomorph, PREM 55299 anamorph, ex-type culture STE-U 1153).

Perithecia orange, globose to ovoid, 350-400 $\mu \mathrm{m}$ high, 300-380 $\mu \mathrm{m}$ wide, turning dark red in $3 \% \mathrm{KOH}$; ostiole papillate, orange to red, generally darker than the perithecium body. Perithecial wall consisting of two layers: outside layer of textura globulosa, 40-50 $\mu \mathrm{m}$ wide; inner layer of textura angularis, $10-30 \mu \mathrm{m}$ wide; hymenial layer of textura prismatica, hyaline, $5-10 \mu \mathrm{m}$ wide; perithecial base up to $100 \mu \mathrm{m}$ wide, consisting of dark red, angular cells. Asci 8-spored, clavate, $80-120 \times 12-18 \mu \mathrm{m}$, tapering to a long thin stalk. Ascospores hyaline, fusoid with rounded ends, straight to slightly curved, 1-septate, constricted at the septum, (28-)33-40(-45) $\times(5-) 6-7(-7.5) \mu \mathrm{m}$. Macroconidiopnores comprising a stipe, a sterile elongation and a penicillate arrangement of fertile branches. Stipe septate, (150-)200(-260) $\mu \mathrm{m}$ long, terminating in a narrowly clavate vesicle, $3(-4) \mu \mathrm{m}$ diam; primary branches aseptate or rarely 1-septate, $15-25 \times 4-5 \mu \mathrm{m}$; secondary and tertiary branches aseptate, 10-15 $\times 4-6 \mu \mathrm{m}$, each terminal branch producing 2-6 phialides; phialides doliiform to reniform, hyaline, non-septate, $10-15 \times 2.5-4 \mu \mathrm{m}$, apex with minute periclinal thickening. Conidia cylindrical, rounded at both ends, straight, (35-) 40-48(-60) $\times 4-5(-6) \mu \mathrm{m}$, 1-septate, lacking a visible abscission scar, held in cylindrical packets by colorless slime. Microconidiophores not observed. Chlamydospores dark brown, walls thickened, formed in moderate numbers throughout the medium, and aggregated to form microsclerotia.

Cultures. Colony color (reverse) 13i sienna (Rayner, 1970). Colonies attaining a radius of $15-18 \mathrm{~mm}$ diam on MEA after $6 \mathrm{~d}$ in the dark at $25 \mathrm{C}$.

Cardinal temperature requirements for growth. Min. above $10 \mathrm{C}$, max. below $35 \mathrm{C}$, opt. $25 \mathrm{C}$. This is a high temperature species, with medium sporulation on aerial mycelium.

Substrate. Soil.

Distribution. Colombia.

Calonectria naviculata Crous et M.J. Wingf., sp. nov. FIGS. 5-8, 12-14

Anamorph. Cylindrocladium naviculatum Crous \& M.J. Wingf., Mycotaxon 50: 443. 1994.

Perithecia rubri-brunnea, globosa ad ovoidea, 350-450 $\mu \mathrm{m}$ alta, 350-400 $\mu \mathrm{m}$ lata, pariete exteriore verrucosa, ostiolo papillato. Asci clavati, in stipitem longum tenuem gradatim angustatae, $70-100 \times 8-12 \mu \mathrm{m}, 2-8$-spori. Ascosporae hyalinae, fusiformes, falcatae, 1(-3)-septatae, ad septa constrictae, guttulatae, (20-) 40-48(-52) $\times(3-) 5-6(-6.5) \mu \mathrm{m}$.

FIGS. 1-4. Calonectria gracilipes and its anamorph Cylindrocladium graciloideum. 1. Asci and ascospores. 2. Conidiophore, clavate vesicles and 1-septate conidia. 3. Section through a perithecium wall showing the various wall layers. Bar $=10 \mu \mathrm{m}$. 4. Vertical section through a perithecium. Bar $=20 \mu \mathrm{m}$. 
Crous et Al.: New Species of Hypocreales
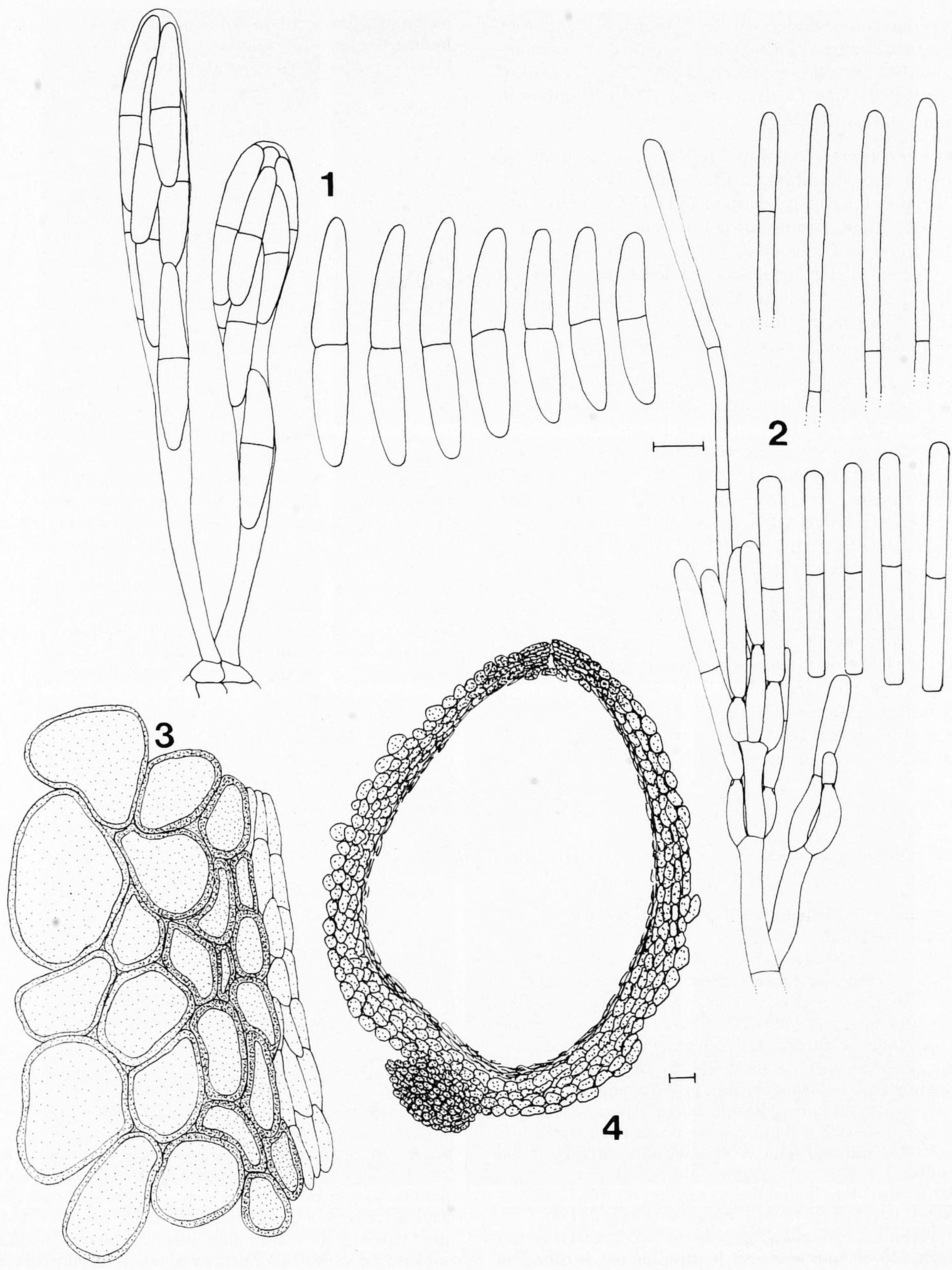

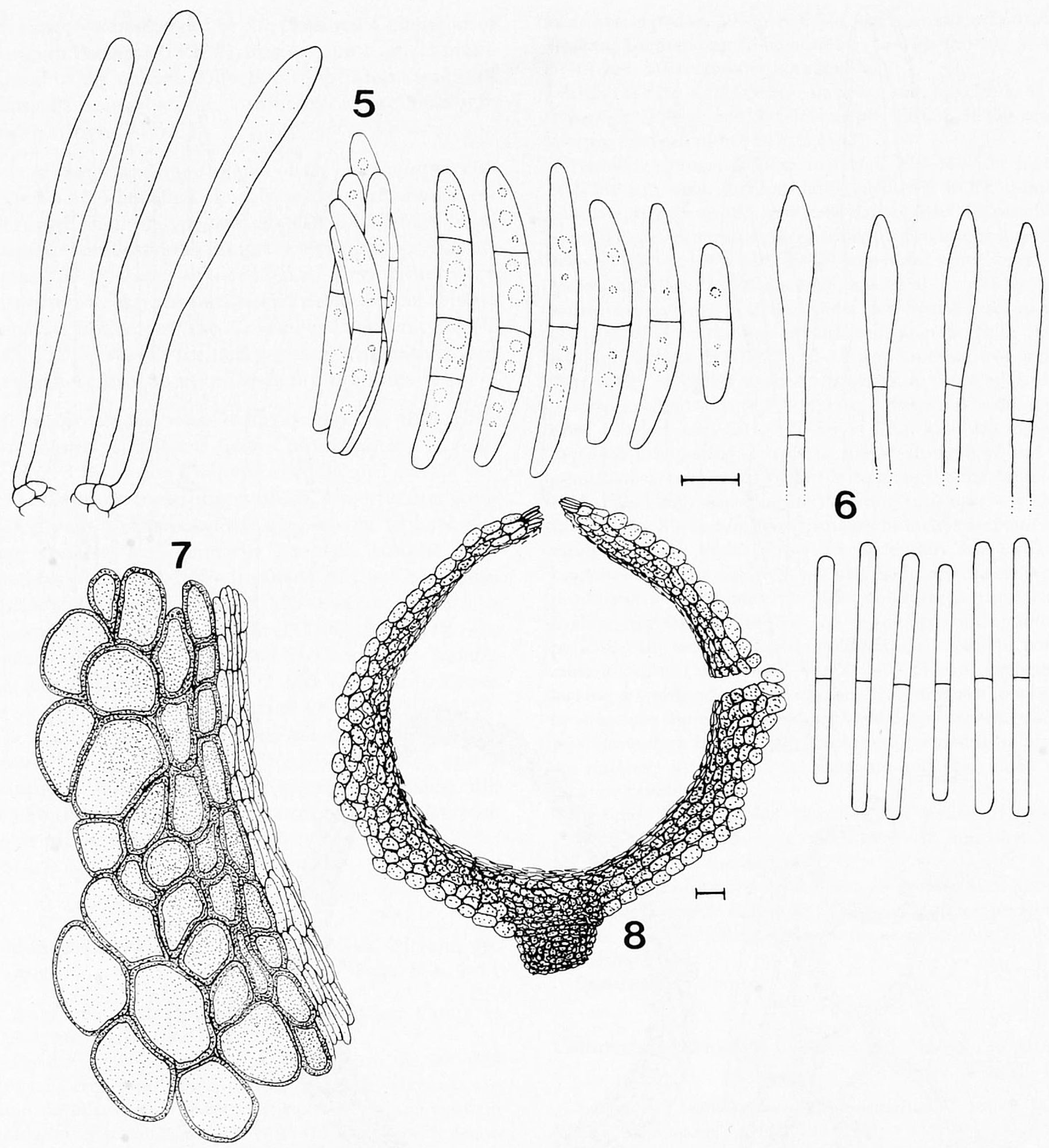

FIGS. 5-8. Calonectria naviculata and its anamorph Cylindrocladium naviculatum. 5. Asci (immature) and ascospores. 6. Naviculate vesicles (above) and 1-septate conidia. 7. Section through a perithecium wall showing the various wall layers. Bar $=10 \mu \mathrm{m}$. 8. Vertical section through a perithecium. Bar $=20 \mu \mathrm{m}$.

HOLOTYPE. BRAZIL $\times$ VENEZUELA. AMAZONAS: soil collected from Manaus (Brazil) and Río Orinoco (Venezuela), respectively, heterothallic mating of STE-U $627 \times$ STE-U 962, Feb. 1995, M.J. Wingfield (PREM 54418).

Perithecia red-brown, globose to ovoid, 350-450 $\mu \mathrm{m}$ high, 350-400 $\mu \mathrm{m}$ wide; ostiole papillate, red, perithecium turning blood red in $3 \% \mathrm{KOH}$. Perithecial wall consisting of two layers: outside layer of textura globulosa, 20-40 $\mu \mathrm{m}$ wide; inner layer of textura angularis, 20-30 $\mu \mathrm{m}$ wide; hymenium layer of textura prismatica, hyaline, 5-10 $\mu \mathrm{m}$ wide; perithecial base up to $80 \mu \mathrm{m}$ wide, consisting of dark red, angular cells. Asci 2- to 8-spored, clavate, 70-100 $\times 8-12$ $\mu \mathrm{m}$, tapering to a long thin stalk. Ascospores hyaline, smooth, fusoid with rounded ends, mostly slightly curved, $1(-3)$-septate, becoming constricted at septa when 3-septate, guttulate, (20-) 40-48(-52) × (3-)5-6(-6.5) $\mu \mathrm{m}$. 

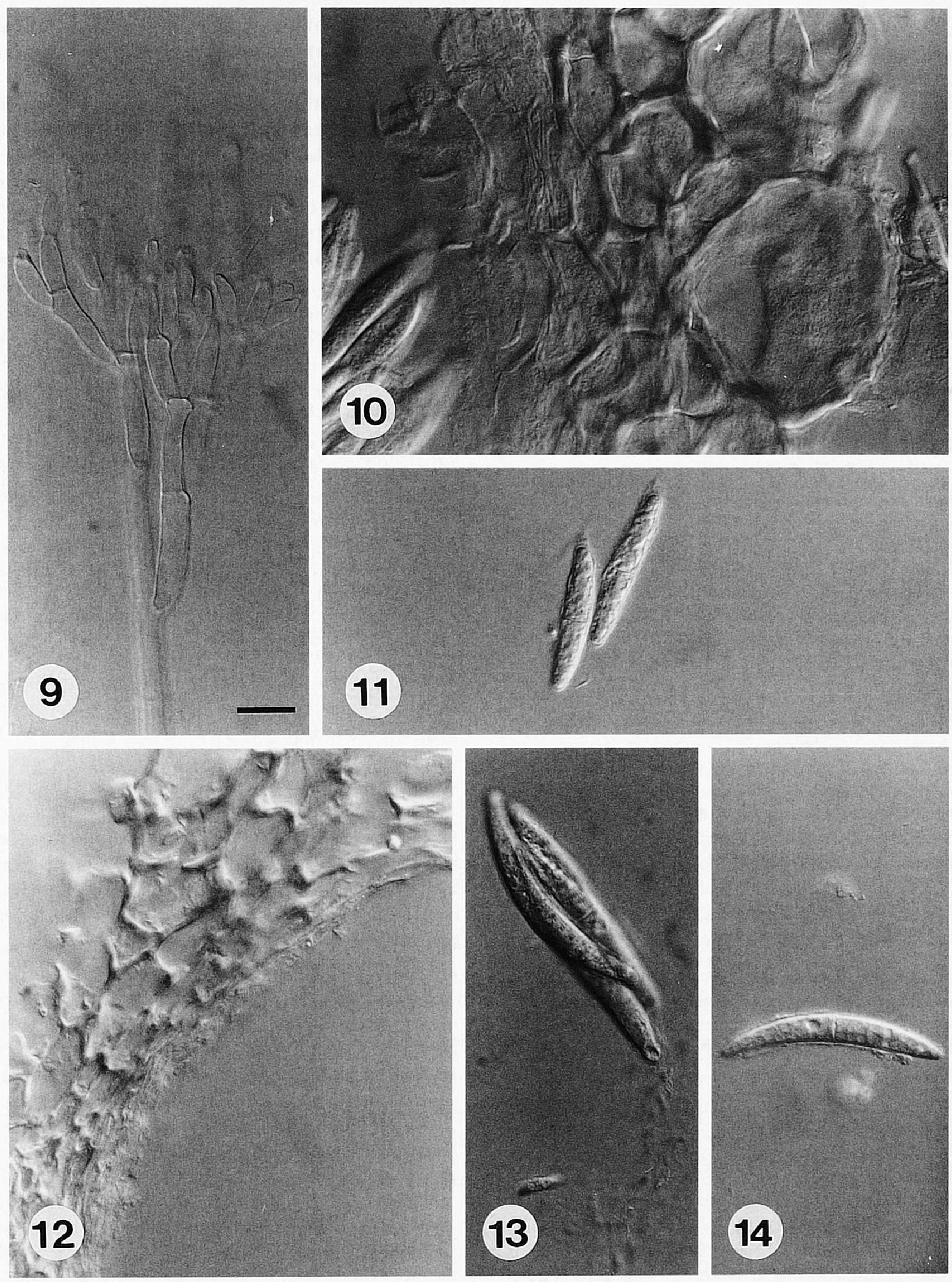

FIGS. 9-14. Calonectria gracilipes and Ca. naviculata. 9-11. Calonectria gracilipes. 9. Penicillate conidiophore of Cy. graciloideum. 10. Section through a perithecium wall. 11. Ascospores. 12-14. Calonectria naviculata. 12. Section through a perithecium wall. 13. Ascus and ascospores. 14. Ascospore. Bar $=10 \mu \mathrm{m}$. 


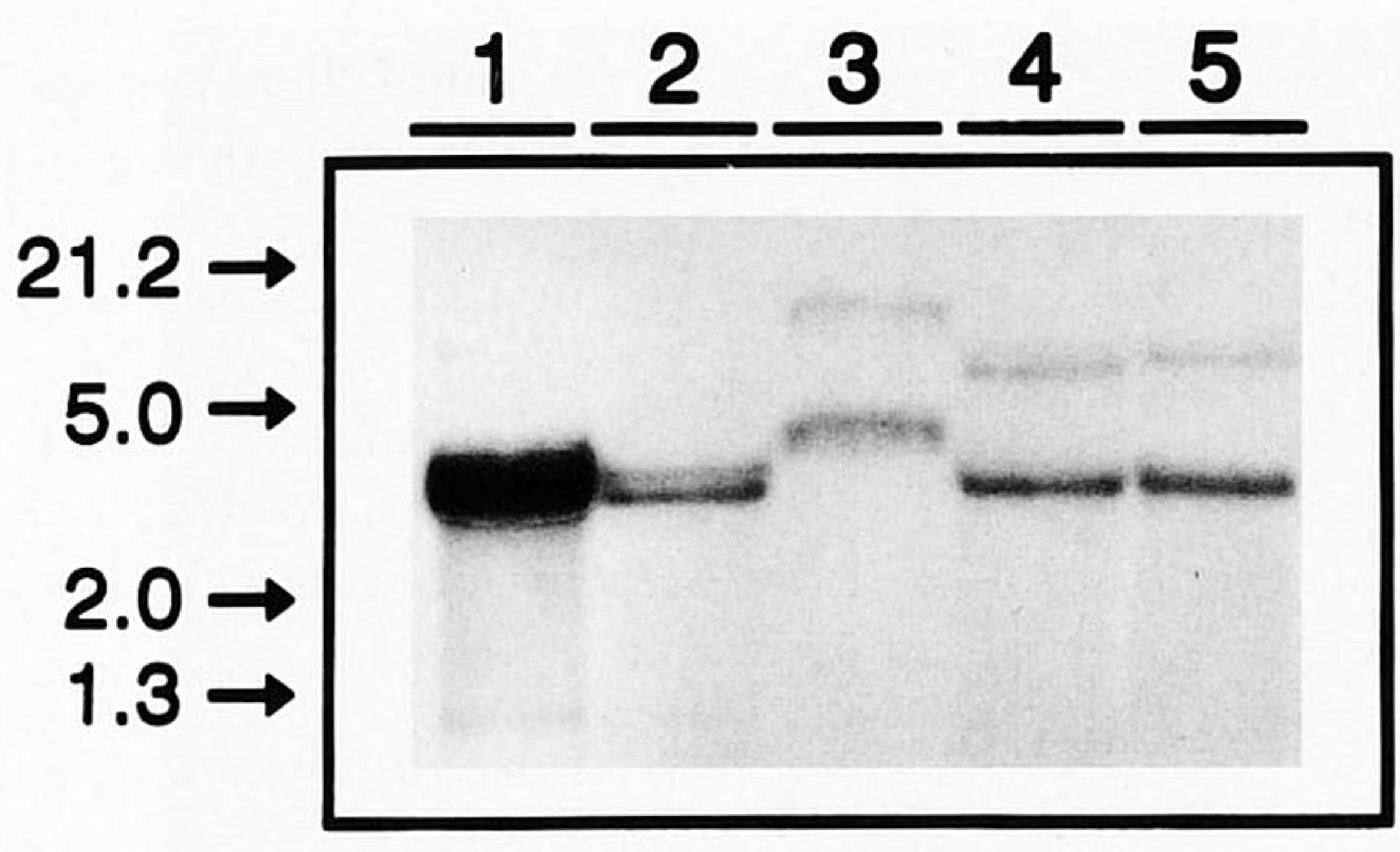

FIG. 15. Ribosomal DNA hybridization patterns for EcoRI digested nDNA of strains of Cylindrocladium and $\mathrm{Ca}$ lonectria species. Lanes 1, 2. Cy. gracile PC 551197 and ATCC 22833. Lane 3. Ca. gracilipes STE-U 1153. Lane 4. Ca. gracilis PPRI 4176. Lane 5. Ca. pteridis PPRI 4157. Size markers are lambda DNA digested with EcoRI and HindIII.

Cultures and cardinal temperature requirements for growth. As reported by Crous et al. (1994).

Substrate. Soil.

Distribution. Brazil, Amazonas state; Venezuela, Río Orinoco, Puerto Ayacucho, Amazonas.

Additional cultures examined. BRAZIL. AMAzONAS: Manaus, soil, Apr. 1993, M.J. Wingfield, STE-U 627-629 (extype of anamorph). VENEZUELA. AMAZONAS: Río Orinoco, Puerto Ayacucho, soil, 1994, M.J. Wingfield, STE-U 947, 955, 961, 962.

\section{DISCUSSION}

Species differences in Cylindrocladium are primarily manifested in conidial size, septation and in the form of the terminal vesicle of the conidiophore. Among the species having clavate vesicles and conidia that are primarily 1-septate, Cy. gracile has been recorded to have a wide range of conidial measurements.
Crous and Wingfield (1994) retained Cy. clavatum (=Cy. brassicae) (conidia 38-52 $\times 4-6 \mu \mathrm{m})$ and $C y$. gracile (conidia $40-56 \times 3.5-5 \mu \mathrm{m}$ ) as separate species despite strong morphological similarity. El-Gholl et al. (1993) identified Cy. clavatum as the anamorph of Ca. clavata Alfieri et al. Crous et al. (1993b) linked Cy. gracile to Ca. gracilis Crous et al. However, in using nrDNA RFLP's, Crous et al. (1995) showed the ex-type strains of Cy. clavatum and Cy. gracile to be identical. The anamorph of Ca. clavata was furthermore found to be misidentified by El-Gholl et al. (1993) as Cy. clavatum (=Cy. gracile), and it was subsequently described as Cy. flexuosum Crous (Crous et al., 1995). To further confuse this issue, the strain described as $C a$. gracilis was incorrectly linked to $C y$. gracile (Crous et al., 1993b), and was thus described as Cy. pseudogracile (Crous et al., 1997). Cylindrocladium spp. in this group are difficult to identify, and it has now become obvious that with several species both morphs are required to accurately identify new strains, and that in problematic cases more specific molecular techniques would have to be employed to confirm identifications.

Cylindrocladium graciloideum (STE-U 1153, 1213) had shorter and wider conidia (35-) 40-48(-60) $\times$ (4-)5(-6) $\mu \mathrm{m}$ than those of Cy. pseudogracile $(40-) 50-58(-65) \times 4(-5) \mu \mathrm{m}$, but was consistent with the variation accepted in Cy. gracile (38-) 40$50(-52) \times 4-5(-6)$ (ATCC 22833), (40-) 45-55(-60) $\times(3.5-) 4-5 \mu \mathrm{m}$ (PC 551197) (Crous et al., 1995). In this species complex, however, the nDNA profiles of Cy. graciloideum digested with the restriction enzymes EcoRI (FIG. 15; TABLE I) and XhoI, proved to be distinct from those of the other two species. Of the Calonectria states described for Cylindrocladium spp. with clavate vesicles and 1-septate conidia, $C a$.

TABLE I. Estimated restriction fragment sizes (bp) of nuclear rDNA probed with the 6.3-kb ribosomal repeat unit of Neurospora crassa

\begin{tabular}{|c|c|c|c|c|}
\hline \multirow[b]{2}{*}{ Species } & \multirow[b]{2}{*}{ Accession no. } & \multicolumn{3}{|c|}{ DNA fragment sizes } \\
\hline & & EcoRI & HindIII & Xhol \\
\hline $\begin{array}{l}\text { Cylindrocladium graciloideum } \\
\text { (teleo. Ca. gracilipes) }\end{array}$ & STE-U 1153 & $\begin{array}{l}6700 \\
4300\end{array}$ & 6400 & 8100 \\
\hline $\begin{array}{l}\text { Cylindrocladium pseudogracile } \\
\text { (teleo. Ca. gracilis) }\end{array}$ & PPRI 4176 & $\begin{array}{l}5700 \\
3900\end{array}$ & 6300 & $>20000$ \\
\hline $\begin{array}{l}\text { Cylindrocladium pteridis } \\
\text { (teleo. Ca. pteridis) }\end{array}$ & PPRI 4157 & $\begin{array}{l}5900 \\
3900\end{array}$ & 6000 & $\begin{array}{r}8300 \\
800\end{array}$ \\
\hline \multirow[t]{2}{*}{$\begin{array}{l}\text { Cylindrocladium gracile } \\
\text { (teleomorph unknown) }\end{array}$} & PC 551197 & $\begin{array}{l}4000 \\
1800\end{array}$ & 13000 & 7500 \\
\hline & ATCC $22833^{a}$ & $\begin{array}{l}4000 \\
1800\end{array}$ & 13000 & 7500 \\
\hline
\end{tabular}

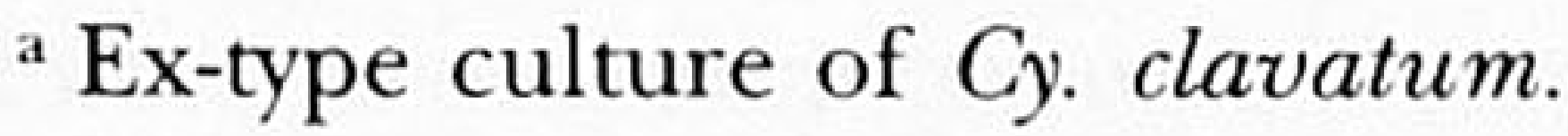


gracilipes can be distinguished by forming orange perithecia with 1-septate ascospores (28-)33-40($45) \times(5-) 6-7(-7.5) \mu \mathrm{m}$, being most similar to, but wider than those of Ca. gracilis (27-) 33-45(-50) $\times$ (4-) 4.5-5(-6) $\mu \mathrm{m}$. Although the nrDNA RFLP profiles of $\mathrm{Ca}$. pteridis and $\mathrm{Ca}$. gracilis were similar except for one distinct band (> 20000 ), spores of $C a$. pteridis [ascospores (30-)52(-75) $\times(4-) 6(-7) \mu \mathrm{m}$, conidia 50-130 $\times$ 4-7 $\mu \mathrm{m}$ ] were much larger than those of Ca. gracilis [ascospores (27-) 33-45(-50) $\times$ (4-) 4.5-5(-6) $\mu \mathrm{m}$, conidia (40-)56(-65) $\times(4-) 5$ $\mu \mathrm{m}$; Crous et al., 1997].

Cylindrocladium naviculatum can be easily distinguished from other species of Cylindrocladium by its characteristically naviculate vesicles, wide stipe extensions, and narrowly 1-septate conidia (40-55 × 3-4 $\mu \mathrm{m}$; Crous et al., 1994). Although several single-conidial strains derived from the type collection from Amazonian Brazil produced protoperithecia on CLA, no fertile perithecia were observed. In mating studies with strains obtained in the present study from soil from Amazonian Venezuela, several combinations among six strains [STE-U $627(+)$ with strains (-) STE-U 955, 961, 962, and STE-U $628(+)$ with strains (-) STE-U 947, 961 and 962] produced perithecia with fertile progeny. The fact that both STE-U 627 and 628 mated with STE-U 961 and 962, suggests that isolates STE-U 627 and 628 are of the same mating type. This would explain the absence of fertile perithecia in the study where this species was described (Crous et al., 1994). Although strains were mated in all possible combinations, STE-U $627(+)$ did not mate with STE-U $947(-)$, nor did STE-U 628 (+) mate with STE-U $955(-)$, suggesting that other factors could also have played a role in these particular matings.

Several media and techniques have been successfully employed in the past to bait Cylindrocladium strains from soil (Crous et al., 1991), and whether the alfalfa technique used in the present study is the most effective, has yet to be determined. Using this technique, however, a number of Cylindrocladium spp. other than those described here were also obtained from the soil samples collected. Samples from Venezuela rendered a few isolates of Cy. pteridis (STE-U 1181, 1182), Cy. candelabrum Viégas (STE-U 1183 ) and Cy. gracile (STE-U 920-922, 938-940). Colombian samples were more rewarding, and were extensively colonized by Cy. reteaudii (Bugnic.) Boesew. (STE-U 1069-1072, 1145-1152, 1165, 1166), and to a lesser extent by $C y$. parasiticum Crous et al. (STE-U 723-725), Cy. gracile (STE-U 726, 1159, 1164) and Cy. candelabrum (STE-U 1160-1163).

Several Cylindrocladium spp. with 1-septate conidia have been linked to Calonectria states similar to $\mathrm{Ca}$. gracilipes and $\mathrm{Ca}$. naviculata. Although these species can be distinguished from each other based primarily on their anamorphs, identifications are greatly simplified if both morphs are formed in culture. Since publication of the initial key to Calonectria spp. with Cylindrocladium anamorphs (Crous and Wingfield, 1994), several new species have been added to the complex discussed in the present study, and thus an emended key is provided below.

\section{KEY TO CALONECTRIA SPP. WITH CYLINDROCLADIUM ANAMORPHS HAVING 1-SEPTATE CONIDIA}

1. Vesicles clavate or clavate to avesiculate ....... 2

1. Vesicles not as above ............... 5

2. Stipe thick-walled, frequently avesiculate, conidia 57-77 $\times 4-7 \mu \mathrm{m}$, perithecia red-brown, ascospores $1(-3)$-septate in ascus, (20-)40-48(-52) $\times(3-$

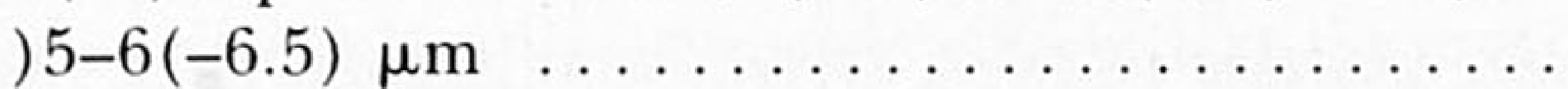
........ Cy. avesiculatum (teleo. Ca. avesiculata)

2. Stipe not thick-walled, never avesiculate, vesicles

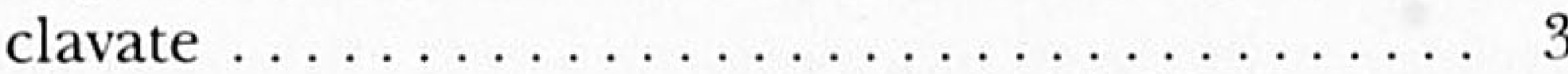

3. Teleomorph unknown; conidia (38-) 40-55(-60) $\times$

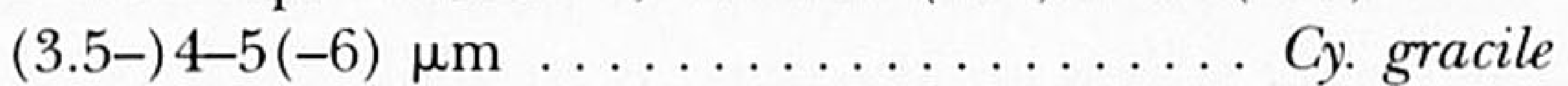

3. Teleomorph readily formed in culture . . . . . . . 4

4. Perithecia orange, conidia (35-)40-48(-60) $\times 4$ $5(-6) \mu \mathrm{m}$, ascospores 1 -septate, mostly constricted at septum, (28-)33-40(-45) $\times(5-) 6-7(-7.5) \mu \mathrm{m}$ ........... Cy. graciloideum (teleo. Ca. gracilipes)

4. Perithecia red-brown, conidia (40-)50-58(-65) $\times$ $4(-5) \mu \mathrm{m}$, ascospores 1-septate, mostly not constricted at septum, (27-)33-45(-50) $\times(4-) 4.5-$ $5(-6) \mu \mathrm{m} \ldots$. . Cy. pseudogracile (teleo. Ca. gracilis)

5 . Vesicles sphaeropedunculate, conidia 35-66 $\times 3-5$ $\mu \mathrm{m}$; perithecia orange-red, ascospores 1-septate in ascus, $(18-) 27-36(-48) \times(4-) 4.5-5(-7) \mu \mathrm{m} \ldots \ldots$. ............ Cy. floridanum (teleo. Ca. kyotensis)

5 . Vesicles not as above, perithecia red-brown . . . . 6

6 . Vesicles naviculate, conidia $40-55 \times 3-4 \mu \mathrm{m}$, ascospores 1(-3)-septate in ascus, (20-) 40-48(-52) $\times(3-) 5-6(-6.5) \mu \mathrm{m} \ldots \ldots \ldots \ldots \ldots \ldots$ ........ Cy. naviculatum (teleo. Ca. naviculata)

6. Vesicles not as above, conidia 33-66 × 3-5 $\mu \mathrm{m}$, ascospores 1-septate in ascus $\ldots \ldots \ldots \ldots 7$

7. Vesicles obovoid to pyriform or ellipsoidal, ascospores (24-) 30-40(-49) $\times(4-) 6-7(-8) \mu \mathrm{m} \ldots \ldots \ldots$ ............. Cy. scoparium (teleo. Ca. morganii)

7. Vesicles obpyriform, rarely ellipsoidal, ascospores (28-) 33-47(-68) $\times(4-) 5-6(-7) \mu \mathrm{m} \ldots \ldots \ldots$ ........... Cy. candelabrum (teleo. Ca. scoparia)

Results of the present and other recent studies (Crous et al., 1995; Victor et al., 1997) provide further evidence that the morphological variation observed in some species in Cylindrocladium and Calonectria can, in many instances be attributed to the lumping of distinct biological species. Of the approximately 20 known species of Cylindrocladium (Crous and Wingfield, 1994; Crous et al., 1995; Victor et al., 1997), only six have not yet been linked to Calonec- 
tria states. This genus has been shown to include both homothallic and heterothallic species. All indications are, therefore, that additional collections will lead to the description of teleomorphs for those species known only in the anamorph state. The soil baiting technique provides a means for collecting isolates from diverse areas and ecological habitats. Utilization of this approach will eventually increase our knowledge of the diversity and mating systems within this group, and facilitate more detailed population studies on species complexes such as Cy. candelabrum (Crous et al., 1993a) and Cy. floridanum (Victor et al., 1997).

\section{ACKNOWLEDGMENTS}

We are grateful to Dr. J. Wright who assisted us in the collection of soil samples from Colombia and Venezuela. We also thank the South African Foundation for Research Development for financial support.

\section{LITERATURE CITED}

Crous, P. W., A. C. Alfenas, and M. J. Wingfield. 1993a. Calonectria scoparia and Calonectria morganii sp. nov., and variation among isolates of their Cylindrocladium anamorphs. Mycol. Res. 97: 701-708.

, A. J. L. Phillips, and M. J. Wingfield. 1991. The genera Cylindrocladium and Cylindrocladiella with ref- erence to forestry nurseries in South Africa. $S$. African Forest. J. 157, 69-85.

$\longrightarrow$, $\longrightarrow$, 1992. Effects of cultural conditions on vesicle and conidium morphology in species of Cylindrocladium and Cylindrocladiella. Mycologia 84: 497-504.

- A. Korf, and W. H. Van Zyl. 1995. Nuclear DNA polymorphisms of Cylindrocladium species with 1-septate conidia and vesicles. System. Appl. Microbiol. 18, 224-250.

- , and M. J. Wingfield. 1994. A monograph of Cylindrocladium, including anamorphs of Calonectria. Mycotaxon 51: 341-435.

- , L. Theron, and W. H. Van Zyl. 1997. Delineating Cylindrocladium spp. with 1-3-septate conidia and clavate vesicles based on morphology and rDNA RFLPs. Mycol. Res. 101: 210-214.

—, M. J. Wingfield, A. C. Alfenas, and F. A. Da Silveira. 1994. Cylindrocladium naviculatum sp. nov., and two new vesiculate hyphomycete genera, Falcocladium and Vesicladiella. Mycotaxon 50: 441-458.

$\longrightarrow,-$, and 1993b. Additions to Calonectria. Mycotaxon 46: 217-234.

El-Gholl, N. E., S. A. Alfieri, Jr., and E. L. Barnard. 1993. Description and pathogenicity of Calonectria clavata sp. nov. Mycotaxon 48: 201-216.

Rayner, R. W. 1970. A mycological colour chart. CMI and British Mycological Society. Kew, Surrey, England. 34 pp. and 17 sheets.

Victor, D., P. W. Crous, B. J. H. Janse, and M. J. Wingfield. 1997. Genetic variation in Cylindrocladium floridanum and other morphologically similar Cylindrocladium species. System. Appl. Microbiol.: In press. 